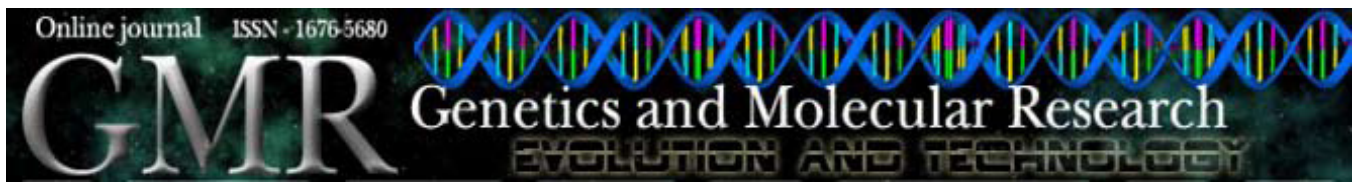

\title{
The first record on Brazilian stingless bees published 450 years ago by Hans Staden
}

\author{
W. Engels \\ Corresponding author: W. Engels \\ E-mail: wolf.engels@uni-tuebingen.de
}

Departamento de Genética, Universidade de São Paulo, Ribeirão Preto, SP, Brasil and Zoological Institute, University of Tübingen, Germany

Genet. Mol. Res. 8 (2): 738-743 (2009)

Received December 12, 2008

Accepted January 26, 2009

Published June 23, 2009

\begin{abstract}
Only a few decades after 1492, when Christopher Columbus arrived on a Caribbean island and Pedro Álvares Cabral claimed Brazil for Portugal in 1500, a German mercenary gave the first description of stingless bees in 1557 . He got to know them when he was imprisoned for months by an anthropophagous tribe in the coastal region of Santos, today in the State of São Paulo. This rather short but nevertheless extremely exact record on stingless bees is hidden in the first book on Brazil. Three species and important aspects of their life history were treated. This early description has been completely overlooked by bee scientists until now. My note intends to close this evident gap.
\end{abstract}

Key words: Stingless bees; First record in 1557;

Hans Staden; Brazil 


\section{INTRODUCTION}

Exactly 450 years ago at carnival the "Warhaftig Historia" (Figure 1) was published in Marburg. The author, Hans Staden (Figure 2) from Homberg in Hessia, was hired as a rifle marksman by the Portuguese and Spanish to capture ships. Between 1547 and 1555 he spent about eight years in Brazil. Tupinamba Indians imprisoned him for over 10 months. The people of this long-extinct tribe were man-eaters. Hans Staden was spared because the chief discovered that he had some medical and shaman knowledge.

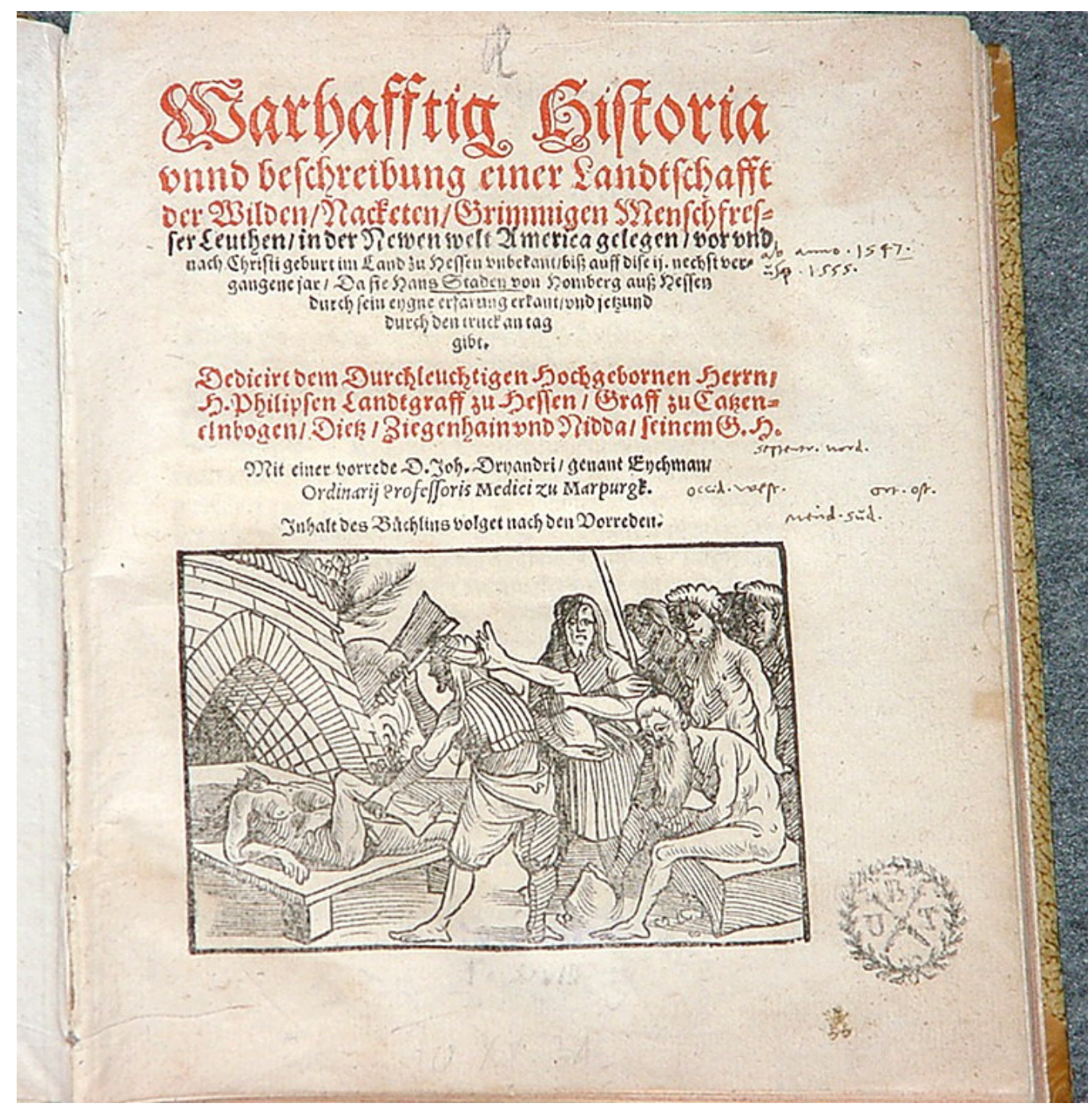

Figure 1. The original book about Brazil published by Hans Staden in 1557. 


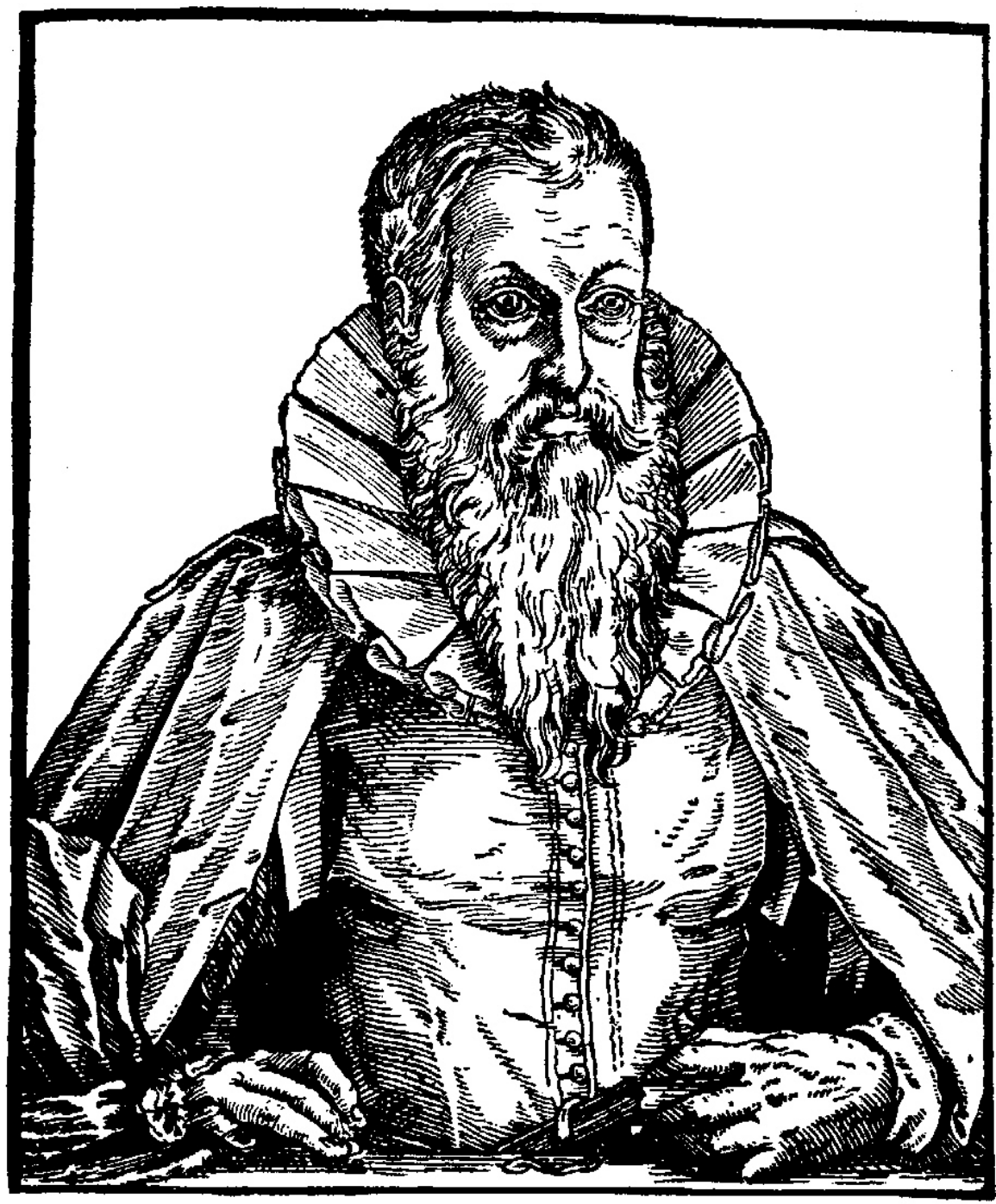

Hans Staden

Figure 2. Drawing of Hans Staden from his book.

\section{MATERIAL AND METHODS}

The information about Hans Staden and his famous first book on Brazil of 1557, including the numerous subsequent editions and the secondary literature on this subject, 
was found in the Rare Books Division of the main library of the University of Tübingen. In their collection of old literature, I found a copy of the first edition of Staden's book, originally owned by Martin Crusius, in those days Chancellor of the University, with his handwritten remarks in Latin and German. The memory of this early Brazil reporter is maintained by the Martius-Staden Institute in São Paulo (IMS, 2007). In 2007, the Regional Museum in Wolfhagen, Hessia, where Hans Staden lived after he came back from Brazil, together with the University of Kiel, organized a symposium on " 450 years after Hans Staden's book on Brazil", and a beautiful exposition was arranged, which subsequently was shown in São Paulo. In Wolfhagen there is a commemorative plaque and a Hans-Staden-Strasse (street). Additional information originated from these sources and the recent bilingual and annotated publication on Hans Staden in the series Fontes Americanae (Obermeier, 2007). In recent issues of the Tópicos these events were commented (Kupfer, 2007).

\section{RESULTS}

The report of his two journeys written in early new High German was the first book on Brazil. The 178-page volume included details concerning the New World. He described the geography of the Atlantic coast, its flora and fauna, the man-eating wild people and many details of their way of life. The book immediately became a best seller. Within a short time, over 80 editions in many languages were printed; it is until today found in bookstores. Several of the 54 wood-engraved illustrations show the author as a bearded white man among the Indians.

Staden's book (Figure 1) is divided into two parts treating his journeys. The description of the second trip lasting about seven years includes detailed biological information. The zoological chapters 30 to 36 entitled "report on several animals in the land" ("Bericht etlicher Thier im lande") begins with two mammals typical to the Brazilian fauna, the Tatu "Die Figur Dattu" (Tolypeutes tricinctus, Figure 3 - an armadillo) and the Gambá "Serwoy" (Didelphis paraguayensis - an opossum), the latter correctly described as a marsupial. Chapter 35 comprises in a short section Staden's knowledge on the indigenous stingless bees: "about the bees of the country" (Figure 4). With not more than 140 words, he described three species of bees. "The first looks very much like our bees, the second is black and the size of a fly. The third, however, is as small as a midge". Evidently he meant Melipona quadrifasciata, Scaptotrigona postica and Tetragonisca angustula. So, this is in fact the first description of three species of stingless bees. He noted that they stored honey in hollow trees and that he often collected honey from all three species together with the wild men. Concerning its quality he judged: "from the smallest we generally collected better honey than from the others". Staden also recognized that these bees do not sting: "sie stechen auch nit so hart wie die bienen hie zu lande". He had often seen that when the Indians collected the honey, the bees flew onto them, and the men had trouble to remove the bees from their naked bodies. He himself had also removed honey naked, but the first time he had to run to water with great pain, to wash them off, in order to get rid of the bees. 


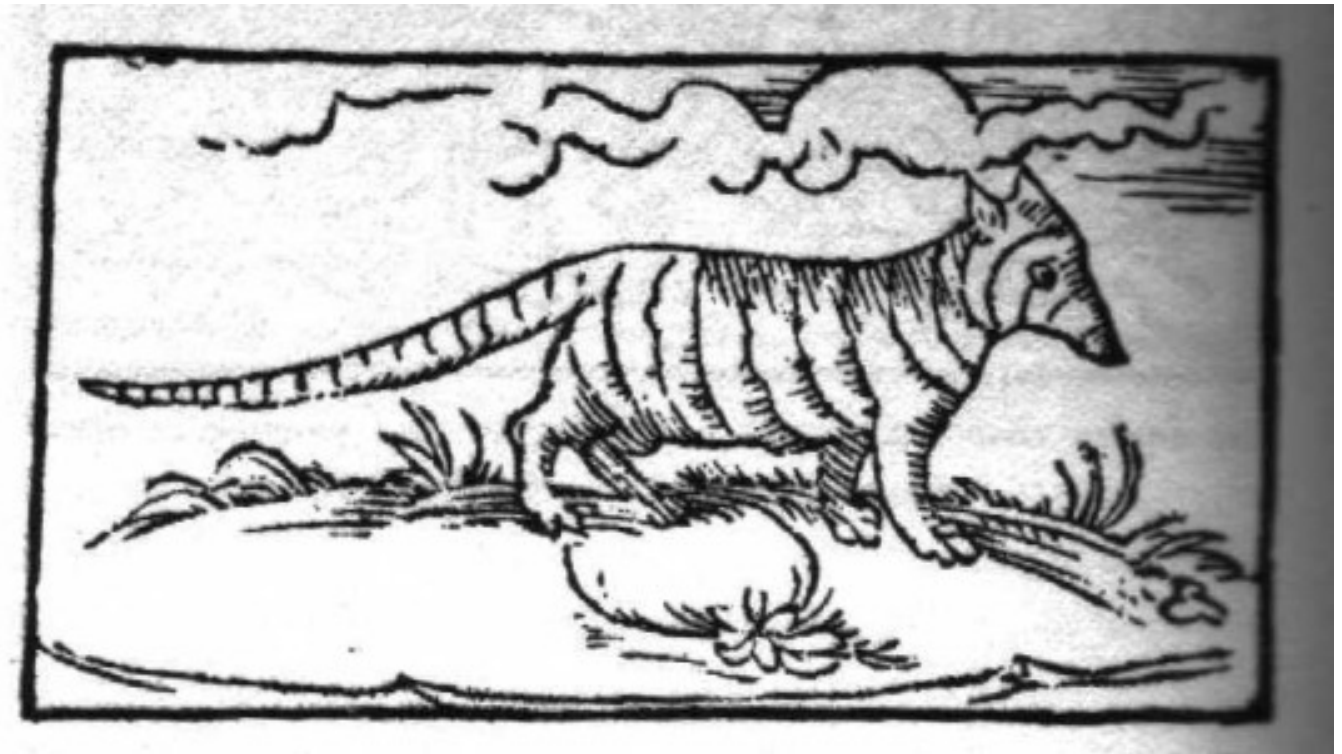

Figure 3. An armadillo from the book by Hans Staden.

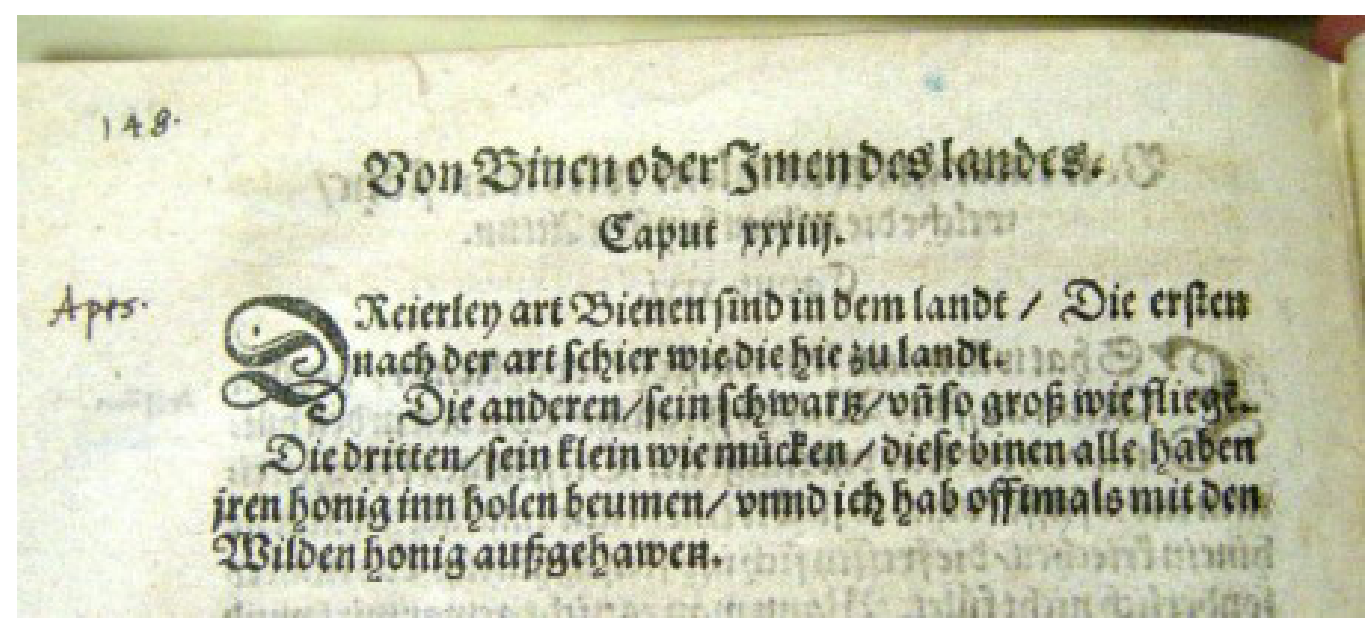

Figure 4. Part of the section written about bees in the Staden book.

\section{DISCUSSION}

This first record of meliponids was hitherto completely overlooked by bee scientists (Michener, 1974; Nogueira-Neto, 1997). Of course this was not a correct description of spe- 
cies in a scientific manner with the proposal of naming them. However, Staden's book was written more than 200 years before Linné established modern taxonomy with binomial Latin names. Nevertheless, this early record on Brazilian meliponids was given so exactly that my identification of the assumed species, all occurring in the region of his stay with the Indians, seems highly probable. Only about 250 years later stingless was classified as a group character, resulting in the common name Stingless Bees, the Meliponini (Michener, 2000).

In fact, Staden had already characterized some of the main groups of meliponids. Evidently he knew quite a bit about their life history. He mentioned hollow trees as their nesting sites, and he gave a dramatic account of the nest defense by these non-stinging bees, biting painfully into the skin of an intruder. He also tested their honey and qualified the Jatai (Tetragonisca angustula) honey as the best - a judgment confirmed by today's market price.

During the past century, stingless bees have become a major subject of research (Makert et al., 2006), best documented at the biannual Encontros sobre Abelhas, organized successfully by the bee research group of the University of São Paulo, in Ribeirão Preto, originally founded by Dr. Kerr. Among his own contributions to bee science only the pioneer caste paper (Kerr, 1950) is quoted here.

In summary, what Hans Staden knew and wrote on Brazilian stingless bees is remarkable, and since his record is now available not only in German (Faber, 1982), but also in Portuguese online versions (Staden, 1557), it is now easy to examine his original work. The first Portuguese edition of Staden's book was already published nearly eighty years ago by Sampaio (1930) but was completely overlooked by bee scientists.

\section{ACKNOWLEDGMENTS}

The valuable University of Tübingen collection of early literary work was made accessible to me by Dr. Gerd Brinkhus, and I appreciate his experienced help very much. Thanks go to Sabine Heinle who provided the reproductions from the first edition of the Staden book and prepared the figures. For long-standing and fruitful cooperation in our research on stingless bees I am grateful to my many Brazilian friends. I appreciate the critical reading of the manuscript by Dr. David De Jong.

\section{REFERENCES}

Faber G (Editor) (1982). Hans Staden, Brasilien. Erdmann Verlag, Tübingen.

IMS (Instituto Martius-Staden) (2007). 450 anos Hans Staden: lançamento de livro e exposição. Tópicos 46: 31.

Kerr WE (1950). Genetic determination of castes in the genus Melipona. Genetics 35: 143-152.

Kupfer EE (2007). Das erste Buch über Brasilien. Tópicos 46: 30-31.

Makert GR, Paxton RJ and Hartfelder K (2006). An optimized method for the generation of AFLP markers in a stingless bee (Melipona quadrifasciata) reveals a high degree of intracolonial genetic polymorphism. Apidologie 37: 687-698.

Michener CD (1974). The Social Behaviour of the Bees. Harvard University Press, Cambridge.

Michener CD (2000). Bees of the World. John Hopkins University Press, Baltimore.

Nogueira-Neto P (1997). Vida e Criação de Abelhas Indígenas sem Ferrão. Edição Nogueirapis, São Paulo.

Obermeier F (Editor) (2007). Hans Staden. Westensee Verlag, Kiel.

Sampaio T (1930). Staden, Hans: Viagem ao Brasil. Academia Brasileira, Rio de Janeiro.

Staden H (1557). Warhaftig Historia und Beschreibung Eyner Landtschafft. Andreas Kolbe Verlag, Marburg. Available at [http://gutenberg.spiegel.de/staden.htm; http://www.obrasraras.usp.br/obras//000152/; http://purl.pt/151]. Accessed July 18, 2007. 